\title{
Front Matter: Volume 8804
}

, "Front Matter: Volume 8804," Proc. SPIE 8804, Neurophotonics, 880401 (26 June 2013); doi: 10.1117/12.2033952

SPIE. Event: European Conferences on Biomedical Optics, 2013, Munich, Germany 


\title{
PROGRESS IN BIOMEDICAL OPTICS AND IMAGING
}

\section{Neurophotonics}

\author{
Francesco Pavone \\ Elizabeth Hillman \\ Vincent Daria \\ Serge Charpak \\ Editors
}

12, 14 May 2013
Munich, Germany

Sponsored by

The Optical Society (United States)

SPIE

With Support From

Air Force Office of Scientific Research (United States)

ThorLabs (United Kingdom)

Student Award Sponsors

Toptica Photonics AG (Germany)

Zeiss (United States)

Published by

SPIE 
The papers included in this volume were part of the technical conference cited on the cover and title page. Papers were selected and subject to review by the editors and conference program committee. Some conference presentations may not be available for publication. The papers published in these proceedings reflect the work and thoughts of the authors and are published herein as submitted. The publisher is not responsible for the validity of the information or for any outcomes resulting from reliance thereon.

Please use the following format to cite material from this book:

Author(s), "Title of Paper," in Neurophotonics, edited by Francesco Pavone, Elizabeth Hillman,

Vincent Daria, Serge Charpak, Proceedings of OSA Biomedical Optics-SPIE Vol. 8804 (SPIE, Bellingham, WA, 2013) Article CID Number.

ISSN: $1605-7422$

ISBN: 9780819498120

Copublished by

SPIE

P.O. Box 10, Bellingham, Washington $98227-0010$ USA

Telephone +1 3606763290 (Pacific Time) · Fax +1 3606471445

SPIE.org

and

The Optical Society

2010 Massachusetts Ave., N.W., Washington, D.C., 20036 USA

Telephone 1 202/223-8130 (Eastern Time) · Fax 1 202/223-1096

http://www.osa.org

\section{Copyright (C) 2013, Society of Photo-Optical Instrumentation Engineers and The Optical Society}

Copying of material in this book for internal or personal use, or for the internal or personal use of specific clients, beyond the fair use provisions granted by the U.S. Copyright Law is authorized by SPIE subject to payment of copying fees. The Transactional Reporting Service base fee for this volume is $\$ 18.00$ per article (or portion thereof), which should be paid directly to the Copyright Clearance Center (CCC), 222 Rosewood Drive, Danvers, MA 01923. Payment may also be made electronically through CCC Online at copyright.com. Other copying for republication, resale, advertising or promotion, or any form of systematic or multiple reproduction of any material in this book is prohibited except with permission in writing from the publisher. The CCC fee code is $1605-7422 / 13 / \$ 18.00$.

Printed in the United States of America.

Publication of record for individual papers is online in the SPIE Digital Library.

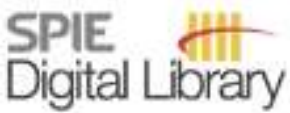

SPIEDigitalLibrary.org

Paper Numbering: Proceedings of SPIE follow an e-First publication model, with papers published first online and then in print and on CD-ROM. Papers are published as they are submitted and meet publication criteria. A unique, consistent, permanent citation identifier (CID) number is assigned to each article at the time of the first publication. Utilization of CIDs allows articles to be fully citable as soon as they are published online, and connects the same identifier to all online, print, and electronic versions of the publication. SPIE uses a six-digit CID article numbering system in which:

- The first four digits correspond to the SPIE volume number.

- The last two digits indicate publication order within the volume using a Base 36 numbering system employing both numerals and letters. These two-number sets start with 00, 01, 02, 03, 04, 05, 06, 07, 08, 09, OA, OB ... OZ, followed by 10-1Z, 20-2Z, etc.

The CID Number appears on each page of the manuscript. The complete citation is used on the first page, and an abbreviated version on subsequent pages. Numbers in the index correspond to the last two digits of the six-digit CID Number. 


\section{Contents}

$\checkmark \quad$ Conference Committee

BRAIN OXYGENATION AND VASCULAR IMAGING

880402 Functional near-infrared spectroscopy at small source-detector distance by means of high dynamic-range fast-gated SPAD acquisitions: first in-vivo measurements [8804-9]

L. Di Sieno, D. Contini, A. Dalla Mora, A. Torricelli, Politecnico di Milano (Italy); L. Spinelli, Istituto di Fotonica e Nanotecnologie, CNR (Italy); R. Cubeddu, A. Tosi, G. Boso, A. Pifferi, Politecnico di Milano (Italy)

880403 Simultaneous imaging of cortical haemoglobin concentration and blood flow with RGB reflectometry and LASCA during cortical activation in rats [8804-4]

A. Steimers, RheinAhrCampus Remagen (Germany); S. Pinkernell, U. Lindaver, Technische Univ. München (Germany); M. Kohl-Bareis, RheinAhrCampus Remagen (Germany)

880404 Multichannel time domain fNIRS mapping of cortical activation and superficial systemic responses during neuromuscular electrical stimulation [8804-11]

R. Re, Politecnico di Milano (Italy); M. Muthalib, Univ. Montpellier 1 (France) and Queensland Univ. of Technology (Australia); L. Zucchelli, Politecnico di Milano (Italy); S. Perrey, Univ. Montpellier 1 (France); D. Contini, M. Caffini, Politecnico di Milano (Italy); L. Spinelli, Istituto di Fotonica e Nanotecnologie, CNR (Italy); G. Kerr, Queensland Univ. of Technology (Australia); A. Torricelli, Politecnico di Milano (Italy)

\section{MICROSCOPY OF THE BRAIN}

880405 Light sheet microscopy of cleared mouse brains: aberrations effects caused by refractive index mismatch [8804-8]

L. Silvestri, European Lab. for Non-Linear Spectroscopy (Italy); L. Sacconi, Istituto Nazionale di Ottica, CNR (Italy) and European Lab. for Non-Linear Spectroscopy (Italy); F. S. Pavone, European Lab. for Non-Linear Spectroscopy (Italy), Istituto Nazionale di Ottica, CNR (Italy), Univ. degli Studi di Firenze (Italy), and Fondazione ICON (Italy)

880406 Probing cell activity in random access modality [8804-3]

L. Sacconi, Istituto Nazionale di Ottica, CNR (Italy) and European Lab. for Non-Linear Spectroscopy (Italy); C. Crocini, J. Lotti, European Lab. for Non-Linear Spectroscopy (Italy); R. Coppini, C. Ferrantini, C. Tesi, Univ. degli Studi di Firenze (Italy); P. Yan, L. M. Loew, Univ. of Connecticut Health Ctr. (United States); E. Cerbai, C. Poggesi, Univ. degli Studi di Firenze (Italy); F. S. Pavone, Istituto Nazionale di Ottica, CNR (Italy), European Lab. for Non-Linear Spectroscopy (Italy), and Univ. degli Studi di Firenze (Italy) 
880407 In vivo two-photon imaging of climbing fibers plasticity after laser axotomy [8804-6] A. L. Allegra Mascaro, European Lab. for Non-Linear Spectroscopy (Italy); P. Cesare, Fondazione Santa Lucia (Italy) and Istituto Nazionale di Neuroscienze (Italy); L. Sacconi, European Lab. for Non-Linear Spectroscopy (Italy) and Istituto Nazionale di Ottica, CNR (Italy); G. Grasselli, Fondazione Santa Lucia (Italy) and Univ. of Chicago (United States); G. Mandolesi, Fondazione Santa Lucia (Italy); B. Maco, G. W. Knott, Ecole Polytechnique Fédérale de Lausanne (Switzerland); V. De Paola, Imperial College London (United Kingdom); P. Strata, Fondazione Santa Lucia (Italy) and Istituto Nazionale di Neuroscienze (Italy); F. S. Pavone, European Lab. for Non-Linear Spectroscopy (Italy), Istituto Nazionale di Ottica, CNR (Italy), Univ. degli Studi di Firenze (Italy), and La Fondazione ICON (Italy)

\section{POSTER SESSION}

880408 Multi-laboratory investigation of the optical properties of the human head [8804-13] A. Farina, Istituto di Fotonica e Nanotecnologie, CNR (Italy); A. Pifferi, Istituto di Fotonica e Nanotecnologie, CNR (Italy) and Politecnico di Milano (Italy); A. Torricelli, I. Bargigia, Politecnico di Milano (Italy); L. Spinelli, Istituto di Fotonica e Nanotecnologie, CNR (Italy); R. Cubeddu, Politecnico di Milano (Italy); F. Foschum, M. Jäger, E. Simon, O. Fugger, A. Kienle, Univ. Ulm (Germany); F. Martelli, P. Di Ninni, G. Zaccanti, Univ. degli Studi di Firenze (Italy); A. Jelzow, Physikalisch-Technische Bundesanstalt (Germany); E. Kirilina, Physikalisch-Technische Bundesanstalt (Germany) and Freie Univ. Berlin (Germany); H. Wabnitz, Physikalisch-Technische Bundesanstalt (Germany); J. Heiskala, M. Schweiger, S. Arridge, Univ. College London (United Kingdom)

880409 5-ALA-induced PpIX fluorescence in gliomas resection: spectral complexity of the emission spectrum in the infiltrative compound [8804-14]

B. Montcel, L. Mahieu-Williame, CREATIS, CNRS, Univ. de Lyon 1 (France); X. Armoiry, Ctr. Hospitalier Univ. de Lyon (France); D. Meyronet, ONCOFLAM, CNRS, Univ. de Lyon 1 (France) and Ctr. Hospitalier Univ. de Lyon (France); J. Guyotat, Ctr. Hospitalier Univ. de Lyon (France)

8804 OA Multispectral imaging of hemodynamics in exposed brain of rat during cortical spreading depression using Wiener estimation method [8804-12]

I. Nishidate, K. Yoshida, C. Mizushima, Tokyo Univ. of Agriculture and Technology (Japan); S. Kawauchi, S. Sato, National Defense Medical College (Japan); M. Sato, Yamagata Univ. (Japan)

$8804 \mathrm{OB}$ A method for discriminating systemic and cortical hemodynamic changes by time domain fNIRS [8804-10]

L. Zucchelli, Politecnico di Milano (Italy); L. Spinelli, Istituto di Fotonica e Nanotecnologie, CNR (Italy); D. Contini, R. Re, A. Torricelli, Politecnico di Milano (Italy) 


\title{
Conference Committee
}

\author{
General Chairs
}

Irene Georgakoudi, Tufts University (United States)

Peter Andersen, Technical University of Denmark (Denmark)

Programme Chairs

Jürgen Popp, Friedrich-Schiller Universität Jena (Germany)

Andreas Hielscher, Columbia University (United States)

Conference Chairs

Francesco Pavone, European Laboratory for Non-Linear Spectroscopy (Italy)

Elizabeth Hillman, Columbia University (United States)

Vincent Daria, The Australian National University (Australia)

Serge Charpak, Institut National de la Santé et de la Recherche Médicale (France)

Programme Committee

George Augustine, Duke-National University of Singapore (Singapore)

David Boas, Harvard Medical School (United States)

Ed Boyden, Massachusetts Institute of Technology (United States)

Turgut Durduran, Institut de Ciències Fotòniques (Spain)

Valentina Emiliani, Université Paris Descartes (France)

Michael Häusser, University College London (United Kingdom)

Fritjof Helmchen, Universität Zürich (Switzerland)

Thomas Knöpfel, RIKEN Brain Science Institute (Japan)

Arthur Konnerth, Technische Universität München (Germany)

Kazuto Masamoto, The University of Electro-Communications (Japan)

Brian Wilson, Ontario Cancer Institute (Canada)

\section{Session Chairs}

1 Highlights of Neurophotonics

Francesco Pavone, European Laboratory for Non-Linear Spectroscopy (Italy)

2 Brain Oxygenation and Vascular Imaging

Vincent Daria, The Australian National University (Australia)

3 Microscopy of the Brain

Serge Charpak, Institut National de la Santé et de la Recherche Médicale (France) 
Poster Session

Andreas Hielscher, Columbia University (United States)

Proc. of OSA-SPIE Vol. $8804880401-6$

Downloaded From: https://www.spiedigitallibrary.org/conference-proceedings-of-spie on 26 Apr 2023 Terms of Use: https://www.spiedigitallibrary.org/terms-of-use 